\title{
EFFECT OF COMPETENCE AND AUDITOR INTEGRITY TO THE AUDIT QUALITY IN THE INSPECTORATE REGENCY OF SERANG (INSPEKTORAT KABUPATEN SERANG)
}

\author{
Verliani Dasmaran*), Alpia Aliana Lukman \\ Fakultas Ekonomi Universitas Mathlaul Anwar Banten \\ *Email: eeytea@gmail.com
}

\begin{abstract}
Research Objective is to know how the auditor's competence and integrity of the auditor has to affect the quality of audit. The object of research is the district inspectorate attack. The population of the research is all civil servants (ASN) working on Inspectorate Serang regency, and samples of research taken in this research are as many as 32 (thirty two) people, with purposive sampling. Quantitative method is used in this research by using questioner in each research variable by using some indicators. The result of the research proves that Audit Competence has a positive effect on audit quality and integrity of auditor positively to audit quality.
\end{abstract}

Keywords: Competency Auditor, Integrity Auditor, Quality Audit

\begin{abstract}
Abstrak
Tujuan Penelitian adalah untuk mengetahui bagaimana kompetensi auditor dan integritas auditor harus mempengaruhi kualitas audit. Objek penelitian adalah serangan inspektorat kabupaten. Populasi penelitian adalah seluruh PNS (ASN) yang bekerja di Inspektorat Kabupaten Serang, dan sampel penelitian yang diambil dalam penelitian ini adalah sebanyak 32 (tiga puluh dua) orang, dengan purposive sampling. Metode kuantitatif digunakan dalam penelitian ini dengan menggunakan kuesioner pada setiap variabel penelitian dengan menggunakan beberapa indikator. Hasil penelitian membuktikan bahwa Kompetensi Audit berpengaruh positif terhadap kualitas audit dan integritas auditor secara positif terhadap kualitas audit.
\end{abstract}

Kata kunci: Auditor Kompetensi, Auditor Integritas, Audit Kualitas

\section{INTRODUCTION}

Good Governance is rooted in deviations from governmental practices such as Corruption, Collusion and Nepotism (KKN). The holding of centralized, 
non-participatory, and non-participative public affairs of public interest has generated a sense of distrust and even antipathy to the existing government regime. The public is not satisfied with the performance of the government that has been trusted as the organizer of public affairs. The various disappointments in the administration led to the demands to restore the ideal functions of government. Good governance emerges as an effort to satisfy the public for the performance of the real bureaucracy.

The general is good governance in accordance with the rules applied in the World Bank version, good governance is a management of solid and responsible development which is consistent with the principles of democracy and efficient markets, avoidance of misallocation of investment funds and the prevention of corruption both politically and administratively run the budget discipline and the creation of legal and political framework for the creation of activity growth in all business sectors, both for government and private in Indonesia that is a cutting-edge breakthrough in creating public trust and to give birth to a reliable and trustworthy managerial form .

According to Mardiasmo (2005), there are three main aspects that support the creation of good governance namely supervision, control and examination. Supervision is an activity carried out by external parties, namely the community and provincial council (DPRD) to oversee the performance of government. Control is the mechanism executed by the executive to ensure that the system and management policies are implemented properly so that the goals of the organization achieved. While the audit is an activity conducted by the independent party and has the professional competence to check whether the government's performance results are in accordance with the established standard.

Government auditing is an important element in the enforcement of good government. However, the practice is often far from expectations. Mardiasmo (2009) explains that there are some weaknesses in government auditing in Indonesia, including the lack of adequate performance indicators as a basis for measuring government performance either central or local government. It is commonly experienced by public organizations because the output generated in the form of public services are not easily measured. In other words, the size of audit quality is still debatable.

Article 9 paragraph (1) of Law Number 15 (2004) states that: "In conducting the audit of state financial management and responsibility, the State audit Agency (BPK) may utilize the results of the internal government supervisory checks." As mentioned above, the role and function of internal audit including important elements in the system of adequate control of the organization. To be able to support the effectiveness of audit implementation by external auditors as the mandate of article 9 paragraph (1) mentioned above, the role and function of internal audit need to be clarified and affirmed.

Related to this context, the question arises how high the level of competence and integrity of the current auditor, and whether the auditor's competence and integrity affect the quality of the resulting audit. It is not an easy thing to maintain the integrity of the auditor. The work experience and 
competencies inherent in the auditor itself is not a guarantee that the auditor can improve the quality of the results of the examination

From the above exposure, the authors are interested to conduct research with the title "The Influence of Audit Competence, Audit Integrity to Audit Quality".

\section{LITERATURE REVIEW}

\subsection{Definition of Competence}

Competence is characteristic of a person who is explicit enough to be shown, which includes knowledge, skills, and behavior, which can result in performance and achievement (Tandiontong, 2016; 288).

Competence is the ability and characteristics possessed by a Civil Servant in the form of knowledge, skills and attitudes of behavior required in the implementation of duties of his office (State Development Audit Agency /BPKP: 2010).

\subsection{Definition of Integrity}

Integrity is an unwavering consistency and firmness in upholding noble values and beliefs, another definition of integrity is a concept that refers to consistency between action and values and principles. In ethics, integrity is defined as the honesty and truth of one's actions. The opposite of integrity is hypocrisy (hypocrisy or hypocrisy). A person is said to have "integrity" if her actions are in accordance with the values, beliefs, and principles she holds (Wikipedia). Simply, the characteristic of a person of integrity is characterized by the only word and deed instead of one whose words cannot be held. A person who has integrity is not a human type with many faces and appearances adapted to his personal motives and interests. Integrity becomes a key character for a leader. A leader who has integrity will gain the trust of his employees. A leader of integrity is entrusted with his or her actions

Integrity is an element of character that underlies the emergence of professional recognition. Integrity is a quality that underlies public trust and is a benchmark (for members to examine all decisions they make) Integrity requires members to be honest, honest and honest, without sacrificing the secrets of service recipients, services and public confidence should not be overwhelmed by personal gain Integrity can accept unintentional mistakes and honest disagreements, but can accept cheating or abolition of principles (Mulyadi, 2014; 56).

\subsection{Definition of Audit and auditor}

Auditing is a process of collecting \& evaluating evidence of measurable information about an economic entity conducted by a competent and independent person to be able to determine \& report the conformity of information with predefined criteria. Auditing should be done by an independent and competent person (Arens, Elder, Beasly, 2015). 
The Government Auditor is the one who is in charge of auditing the financial at government agencies. In Indonesia, government auditors can be divided into two:

1) The Government External Auditor conducted by State Audit Agency (BPK) as the embodiment of Article 23E Paragraph (1) of the 1945 Constitution which reads To examine the management and responsibility of the state finances shall be established a free and independent Audit Agency. 2) The results of state financial auditors shall be submitted to the house of Representative, the Regional Representative Council, The Supreme Audit Board is a body that is not subject to government, so it is expected to be independent.

2) Government Internal Auditor or better known as Government Functional Supervisory Apparatus (APFP) implemented by State Development Audit Agency (BPKP), Inspectorate General of Department / LPND and Regional Supervisory Board.

\subsection{Definition of Quality Audit}

Understanding the quality according to (Tandiontong, 2016; 199) is the level or degree of good quality bad something. Something here can be a good or service. Measurement of the degree of good or bad quality of goods or services must be associated with the fulfillment of certain criteria, which have been mutually agreed.

There are four groups of audit quality definitions according to Watkins et al (2004) in (Tandiontong, 2016; 79) as follows:

1) De Agelo (1981), audit quality as the probability of market appraisal that financial statements contain material faults and auditors will find and report the material errors.

2) Lee, Liu, and Wang (1999). The quality of the audit according to them is the probability that the auditor will not report the audit report with an unqualified opinion for a material report containing material errors.

3) Titman and Trueman (1986), Beaty (1986), Krinsky and Rotenberg (1989), and Devidson and Neu (1993). According to them, audit quality is measured from the accuracy of information reported by auditors.

4) Wallance (1980) audit quality is determined from auditing ability to reduce noise and bias and improve the purity (fineness) on accounting data.

\subsection{Previous studies}

1) Kurnia Ariati K, Rahardja Rahardja (2014) "The Influence of Auditor Competence on Quality Audit with Spiritual Intelligence as Variable" (Study of Auditor's Perceptions on Financial and Development Supervisory Board of Central Java Province) Based on the result of this research, the conclusion is: (1) the auditor positively affects audit quality and (2) spiritual intelligence does not affect the relationship between auditor competence and audit quality.

2) M. Yusup (2014) "The influence of auditor competence, objectivity and auditor integrity on the quality of audit work" (case study at BPKP Riau Province Representative). The results of this study proves that there is a significant influence between competence, objectivity and auditor's integrity on the quality of results audit work. 


\subsection{Theoritical Framework}

The following is the theoritical framework in this study:

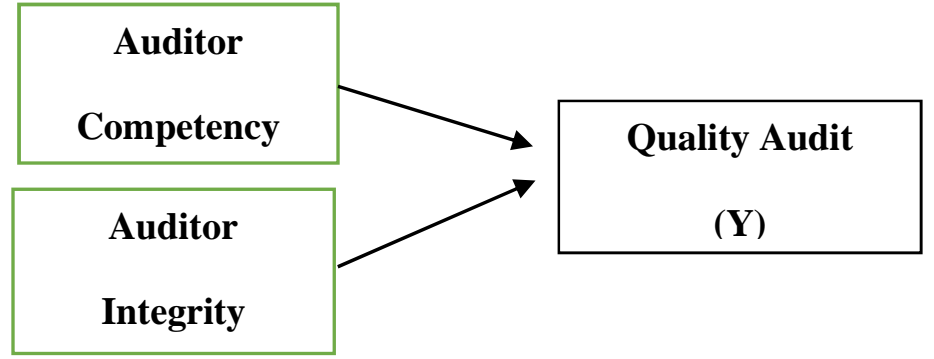

\subsection{Hypothesis Development}

The following are the alternatives of hypothesis in this study:

$\mathrm{H}_{1}$ : Auditor's competence gives positive influence to audit quality

$\mathrm{H}_{2}$ : Auditor's Integrity gives positive influence to audit quality Finding

\section{RESEARCH METHODOLOGY}

\subsection{Population}

Population is a generalization region consisting of: objects / subjects that have certain qualities and characteristics set by the researchers to study and to draw conclusions (Sugiono, 2014; 80). The population in this study is all civil servants (PNS) working on Inspectorate Serang regency, amounting to 51 people.

\subsection{Sample}

The sample size in this study uses the purposive sampling technique, because the researcher only include the State Civil Apparatus (ASN) which has the authority to receive the audit result and some civil servants who are on the examination object which consists of: 1 (one) Inspector, 4 (four) Regional Superintendent Inspectors, 3 (three) Head of Sub-sections, 16 (sixteen) Executors and 8 (eight) functional persons. In (Sugiono, 2014; 85) it is said that Purposive Sampling is a sampling technique by considering certain. So the sample taken in this research is 32 (thirty two) people.

\section{Variable Operatinalization}

\begin{tabular}{|c|c|l|l|l|}
\hline No & Variabel & \multicolumn{1}{|c|}{ Indikator } & Skala & Item \\
\hline 1 & \multicolumn{1}{|c|}{$\begin{array}{c}\text { Auditor } \\
\text { Competence(X1) }\end{array}$} & $\begin{array}{l}\text { 1. Knowledge possessed } \\
\text { 2. expertise possessed } \\
\text { 3. Behavioral attitudes possessed } \\
\text { 4. Knowledge of inspection standards } \\
\text { collectively }\end{array}$ & Ordinal & $1-5$ \\
& & & $6-11$ \\
& & & $12-16$ \\
\hline
\end{tabular}




\begin{tabular}{|c|c|c|c|c|}
\hline 2 & $\begin{array}{l}\text { Auditor } \\
\text { Integrity } \\
\text { (X2) }\end{array}$ & $\begin{array}{l}\text { 1. Personality based on honest behavior } \\
\text { 2. Brave } \\
\text { 3. Wise to the task carried. } \\
\text { 4. Responsibility }\end{array}$ & Ordinal & $\begin{array}{l}1-5 \\
6-10 \\
11-15 \\
16-20\end{array}$ \\
\hline 3 & $\begin{array}{l}\text { Quality Audit } \\
\text { (Y) }\end{array}$ & $\begin{array}{l}\text { 1. Implementation of the audit in accordance } \\
\text { with the standards } \\
\text { 2. Quality of inspection report results: } \\
\text { - On time } \\
\text { - Complete } \\
\text { - Accurate } \\
\text { Objective } \\
\text { - Convincing } \\
\text { Obviously } \\
\text { - Concise } \\
\text { 3. Follow up on audit recommendations }\end{array}$ & Ordinal & $1-5$ \\
\hline
\end{tabular}

\subsection{Data Analysis Method}

\subsubsection{Validity Test}

Validity test is conducted to measure whether questionnaires are valid or not. A questionnaire is considered valid if the questions on it are able to reveal something that will be measured by the questionnaire.

\subsubsection{Reliability test}

Reliability test is a tool to measure the stability and consistency of the respondents in answering issues related to the questions that are indicators of a variable and arranged in a form of a questionnaire.

3.3.3 Descriptive statistical analysis

Descriptive statistics is statistics conducted to analyze data by describing or depicting the collected data without intending to apply general conclusions or generalizations.

\subsubsection{Hypothesis testing}

1) Coefficient of Determination $\left(R^{2}\right)$ Test

Coefficient of determination (Kd), the square of correlation, is conducted to see how big the correlation between variables of $\mathrm{X} 1$ and $\mathrm{X} 2$ and variable $\mathrm{Y}$. significant level of 0.05 to determine the correlation between independent variables simultaneously and dependent variables.

2) Correlation Test

Correlation is a test to see how much relation between audit competence variable and audit integrity to audit quality

3) Individual or Partial Test (T Test) 
$\mathrm{T}$ test is conducted to find out whether the assumption is true or not. The T test is a procedure that allows a decision to be accepted or rejected on the proposed assumption or hypothesis

\section{RESULT AND DISCUSSION}

\subsection{Data Description}

1. $X_{1}$ (Auditor competence) with total data of 32 , the Minimum is 68 , the Maximum is 95, the Mean is 87.44, the Standard Deviation is 6.069, and the Variant is 36.835 .

2. $\mathrm{X}_{2}$ (Auditor Integrity) with total data of 32 , the Minimum is 79 , the Maximum is 94, the Mean is 86.50, the Standard Deviation is 3.793, and the Variant is 14.387.

3. Y (Quality Audi) with total data of 32, the Minimum is 68, the Maximum is 96 , the Mean is 86.72 , the Standard Deviation is 5.704, the Variant is 32.531

\subsection{The Result of Validity Test}

Validity test is used to test the extent to which the accuracy of the measuring tool can reveal the concept of the measured phenomenon / event, the questionnaire item is valid if the value is $\mathbf{r}_{\text {count }}>\mathbf{r}_{\text {tabel }}$. Testing the validity using the formula Pearson product moment and $r$ table value is $\mathbf{0 . 3 4 9}$ results of all instrument studies have value $r$ count $>r_{\text {table }}$ means that all research instruments in each variable is valid

\subsection{The Result of Reliability Test}

The purpose of Reliability Test done by researchers is to assess the consistency of objects and data, whether the instrument used multiple times to measure the same object, will produce the same data. To test the reliability in this research, the researcher use Internal Consistency method with split technique from Spearman Brown (Split Half).

Indicator of reliability measurement by (Sekaran, 2000; 312) which divides the level of reliability with the following criteria: If alpha or $r$ arithmetic:

$>0.8-1.0=$ Good reliability

$>0.6-0.799=$ Reliability is accepted

$>$ less than $0.6=$ Unfavorable reliability

Variable reliability test (X1) Competence Auditor writer using split half technique, Judging from the calculation by using Spearman Brown formula then, the results obtained $r_{i}=\mathbf{0 . 8 1 2}$, while the known value of $r_{\text {table }}=\mathbf{0 . 3 4 9}$ this indicates that the study variable $\mathrm{X}_{1}$ Competence Auditor is Good reliable

Variable reliability test (X2) Integrity Auditor product moment correlation value between the hemispheres $(r b)=0.624$, and the result of $r_{i}=\mathbf{0 . 7 6 8}$, while the known $r_{\text {table }}=\mathbf{0 . 3 4 9}$ this indicates that the research variable (X2) Integrity Auditor is reliable, reliability is accepted 
Variable (Y) Audit quality obtained result $(\mathrm{rb})=0,598$, and value of $\mathrm{ri}=$ 0,748 , while known $r_{\text {table }}$ value $=0,349$ this indicates that research variable $(\mathrm{Y})$ Audit Quality is reliable, reliability is accepted

\subsection{The Result of Correlation}

Correlation test is used to determine the level of relationship between research variables, the value of $r$ (correlation) obtained interpreted in accordance with the table (Riduwan and Sunarto, 2011; 81) then the results of research

1. The value of $\operatorname{rx}_{1} \mathrm{Y}=0.64$ means that the level of audit competence relation with strong category audit quality

2. The value of $\mathrm{rx}_{2} \mathrm{y}=0.618$ means that the level of audit integrity relationship with strong category audit quality

3. The value of $\mathrm{r} \times 1 \times 2 \mathrm{y}=0.753$ means that the level of competence relation and integrity audit strong category, the level of relationship is simultaneously stronger than partial.

\subsection{The Result of Determination Test}

The attached table of the test of coefficient of determination shows that the value of the coefficient of determination seen from the Adjusted $\mathrm{R}$ Square is 0.567. It means that $56.5 \% \mathrm{Y}$ can be explained by the second variation of independent variables, namely the perception and interest, while the remaining of $43.5 \%(100 \%-56.5 \%)$ is explained by other causes outside the model or other variables that are not examined.

\subsection{The Result of Partial Test (t Test)}

Hypothesis testing is done to get a picture of how much the influence of auditor competence and auditor integrity to audit quality At Serang Inspectorate, in this case to test the hypothesis of the authors use $t$ test, test results

The influence of audit competence on audit quality (tx1y) resulted in t count of 4.562 and $t$ table 1.69. This proves $t$ arithmetic $>t$ table so it can be concluded that hypothesis there is a positive influence of competence on audit quality accepted or proven.

The influence of audit integrity on audit quality (tx $2 y)$ produces $t$ count 4.305 and t table 1.69. This proves $t$ arithmetic $>t$ table so it can be concluded that the hypothesis there is a positive influence of audit integrity on audit quality accepted or proven.

\section{CONCLUSION}

Based on the discussion presented about the Competence and Integrity Auditor on Audit Quality at the Inspectorate of Serang District before and related to the existing data, it can be concluded that there is a significant influence between auditor competence on audit quality at Inspectorate of Serang District. Evidenced by the value of $\mathrm{r}=0.64, \mathrm{Cd}=41 \%$, and test results significance Test- $\mathrm{t}$ obtained t-count equal to 4.56 . 
There is a significant influence between auditor integrity on audit quality at Inspectorate of Serang Regency. Evidenced by the value of $\mathrm{r}=0.618, \mathrm{Cd}=$ $38 \%$, and test results significance Test-t obtained t-count 4.305 .

Based on the results of research done then the suggestion proposed in this research, the upcoming one should do a research by using direct interview method, because in this study researchers only use the questionnaire, so there are still possible weaknesses encountered, such as inaccurate answers, not serious and respondents who answered carelessly and dishonestly and questions that are incomplete or poorly understood by the respondents.

\section{REFERENCES}

Harahap, Lukman. (2015). Pengaruh Kompetensi, Independensi, Obektivitas, dan Sensitivitas Etika Profesi Terhadap Kualitas Hasil Audit. Yogyakarta: Universitas Negeri Yogyakarta.

Hery. (2016). Auditing dan Asurans. Jakarta: PT Grasindo, Anggota lkapi.

Mulyadi. (2002). Auditing Buku 1, Edisi 6. Jakarta: Salemba Empat.

Peraturan Menteri Pendayagunaan Aparatur Negara. (2008). Kode Etik Aparat Pengawasan Intern Pemerintah.

Peraturan Menteri Pendayagunaan Aparatur Negara. (2008). Standar Audit Aparat Pengawasan Intern Pemerintah.

Peraturan Bupati Serang. (2015). Pedoman Pengawasan Intern Pemerintah Kabupaten Serang.

Riduwan. (2012). Dasar-dasar Statistika. Bandung: Alfabeta.

Riduwan dan Sunarto. (2011). Pengantar Statistika untuk penelitian:Pendidikan, Sosial, Ekonomi, Komunikasi dan Bisnis. Bandung: Alfabeta.

Sugiono. (2011). Metode Penelitian Kuantitatif, Kuaitatif, dan $R \& D$. Bandung:Alfabeta.

Sugiono. (2014). Metode Penelitian Kuantitatif, Kuaitatif, dan R\&D. Bandung:Alfabeta.

Sukriah, dkk. (2009). Pengaruh Pengalaman Kerja, Independensi, Obyektifitas, Integritas dan Kompetensi Terhadap Kualitas Hasil Pemeriksaan. Skripsi. Semarang: UniversitasNegeri Semarang.

Tandiontong, Mathius. (2016). Kualitas Audit dan Pegukurannya.Bandung: Alfabeta.

Ulum, Ihyaul. (2012). Audit Sektor Publik. Jakarta: Bumi Aksara.

Umar, Husein. 2014. Metode Penelitian untuk Skripsi dan Tesis Bisnis. Jakarta: Rajawali Pers. 